\section{Improving Teacher's Performance Quality in The Freedom to Learn Program Using Zone-Based Lesson Study by Exchanging Teachers}

\author{
Ninik Kristiani \\ High School Supervisor in Malang, Indonesia \\ Email:ninikkristiani1967@gmail.com
}

http://ojs.unm.ac.id/index.php/Insani/index

Abstract. This study aims to investigate the implementation of the strategy of zone-based lesson study by exchanging teachers in order to improve teacher performance, including (1) designing RPPs in accordance with the Circular Letter (SE) of the Indonesian Ministry of Education and Culture (Mendikbud) No. 14 of 2019 concerning the Simplification of RPPs (lesson plans); (2) designing teaching materials such as UKBM (Self-Study Activity Unit) and LKPD (Student Worksheet); (3) implementing Freedom to Learn (FTL); and (4) increasing student participation during FTL. Besides, the strategy can also prepare teachers to become zone organizer teachers. Data were collected for two cycles in which each cycle had two meetings. Data were analyzed through reduction, interpretation, inferences, follow-up, and conclusion. The research subjects were the best quality teachers in their subjects: 1 Biology teacher and 1 History teacher from three schools in cycle 1; and 1 Math teacher and 1 Sociology teacher from two schools in cycle 2. The number of schools where treatments were given in cycle 2 was reduced to follow SK (decree) issued at the end of cycle 1, stating that one of the schools is beyond the target school area. Results showed that the strategy of zone-based lesson study by exchanging teachers can facilitate the improvement of teacher's performance quality, the path for teachers to become zone organizers, and the work production for professional development as a result of collaboration between supervisors, principals, and teachers.

Keywords: teacher's performance quality, freedom to learn, zone-based lesson study by exchanging teachers
INDONESIAN JOURNAL OF EDUCATIONAL STUDIES (IJES)

\section{E-ISSN: 2621-6744 \\ P-ISSN: 2621-6736}

Submitted: April, $2^{\text {nd }} 2020$

Accepted: May, $2^{\text {nd }} \mathbf{2 0 2 0}$

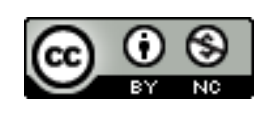

This work is licensed under a Creative Commons Attribution-NonCommercial 4.0 International License 


\section{INTRODUCTION}

Freedom to Learn (FTL) is currently a popularly discussed topic. There are previous studies conducting this topic (Elihami, 2019; Abidah et al., 2020; Mustaghfiroh, 2020; Nehru, 2019). FTL is defined as the freedom of thinking and reasoning to produce creative and innovative ideas. According to Tilaar (2000), freedom is needed to create independent and responsible students. Freedom is related to the efforts to create harmony in society. Furthermore, every human being is believed to have the ability to respond to responsible freedom. To become a whole and responsible person needs a long process called learning. Binding rules are considered to be the killers of creativity and innovation, which are important in a person's life. Rules that bind and restrict freedom to be creative and innovative will gradually be replaced by codes that liberate students. However, the right and responsible mindset is needed to understand FTL. In fact, with freedom comes great responsibility. If the right mindset is not used to understand FTL, misinterpretation will be unavoidable. Thus, the FTL realization will need synchronization and coordination between the three centers of education: government, schools, and families or society.

FTL does not mean to be completely free in learning, but it requires guidance from responsible teachers. Teachers with quality performance will be able to develop creativity and innovation. They will also be able to perform the assigned main tasks properly. Performance, according to Supardi (2013), is the overall ability, workload, and responsibility to achieve the productivity and quality of the assigned work. Teachers are the spearhead of FTL. However, competencies that vary between teachers need to be properly mapped out. School supervisors are assigned to oversee the implementation of education standards and to assess teacher performance in order to successfully map out teacher quality. The mapping can provide school supervisors with data of teacher competencies used for developing, guiding, and training teachers in accordance with the objectives.

FTL demands teachers to be creative and innovative. School principals, assisted by school supervisors, are obliged to improve teacher competencies so that teachers can implement FTL effectively. Four policies of FTL developed by Mendikbud include School Examinations which will be replaced in accordance with the Regulation of Menndikbud (Permendikbud) No. 43 of 2019; UN (National Examination) which will be replaced with AKM (Assessment of Minimum Competency) and Survey of Character; lesson plans (RPPs) which will be simplified; and PPDB (New Student Admissions) which will be made more flexible. Among the four policies, the focus of this study is the simplification of RPPs. The planning and implementation of learning in the context of FTL start with RPPs and teaching materials. Thus, these two elements should be prioritized for quality improvement.

Kristiani (2019) stated that teacher performance needs to be improved. Based on the 2019 data of evaluation of learning tools, almost all teachers had learning tools, such as annual program and semester program, syllabi, and tools of evaluation. However, only $49 \%$ of teachers ensured that the lesson plans met the process standards and the $21^{\text {st }}$ century demands. In fact, $40 \%$ of RPPs were found to be the results of copy and paste. Such teachers merely completed administrative 
work and had no awareness that the primary duty of a teacher, among other things, is to create lesson plans. This phenomenon is not in accordance with Permendikbud No. 15 of 2018 Article 3 Paragraph (1), stating that the main responsibilities of a teacher are to prepare lesson plans, to implement lesson plans, to grade students' works, to train and guide students, and to carry out additional tasks attached to the implementation of the main activities according to teacher's workload. If the main tasks are not properly fulfilled yet, it is feared that teachers will view FTL as freedom from the demands of developing learning tools. Such teachers are not prepared for FTL. This finding is in line with what Danim (2010) revealed that teachers have not shown sufficient work performance. Thus, effective and efficient strategies oriented to the needs of teachers are needed to improve teacher performance for FTL implementation.

The RPP simplification policy that initially highlighted 13 aspects, but is currently reduced to 3 core components, namely learning objectives, learning activities, and assessments, has provided teachers with convenience. This moment is used by the writer to foster the improvement of teacher performance in FTL era. This effort is reinforced by Danim (2010) and Slameto (2013) who found that if teacher performance is poor, students are less likely to absorb concepts optimally and to develop characters and life skills ideally. Consequently, the efforts to improve teacher performance should be addressed first.

Strategies for the improvement of teacher's work performance that the writer frequently applies in schools are workshops and IHT, which are classical. Teachers with different levels of competencies, such as Very Good (VG), Good (G), Fair (F), and Poor (P) are treated equally. However, these strategies seem to be ineffective to enhance teacher's work performance. Never has the writer adopted the strategy by preparing high quality teachers to become zone organizers in the target schools. The writer frequently monitors how teachers perform when implementing lessons in the classroom, but has never taken an initiative to monitor teachers from different schools. Teacher exchange poses a possibility of teachers being much more ready to teach using necessary equipment, compared with teachers teaching in their own schools. This freedom method needs to be applied to improve teacher performance in FTL era.

Given the problem of the quality of teacher performance and problem solving experience with no ideal results, the writer conducted this study by implementing a different strategy, which is called zone-based lesson study by exchanging teachers. This is an innovative strategy since it is a very novel idea. The strategy is also in agreement with the demands of FTL policy and zone organizer teacher policy. Lesson study that has been commonly executed is school-based, but zone-based lesson study by exchanging teacher has never been implemented before.

The strategy of zone-based lesson study by exchanging teachers has strengths that can be used to tackle the problem of teacher performance. Teachers who participate in teacher exchange program seem to be more prepared because they teach students from other schools. This activity has the potential to continuously improve learning quality. Through this strategy, teachers are 
encouraged to be able to collaborate and communicate with other teaches at the plan stage in which they will plan lessons together and to apply the results at the Do and See stage in different schools. This activity can be a good place for sharing, teaching-loving-caring between teachers and between schools, breaking down the barriers between juniors and seniors and between civil servants and non-civil servants. Furthermore, teachers will become more open, thirsty for new knowledge, and even eager to be agents of change in their own schools. Due to its considerable number of advantages, the writer believes that this strategy is able to improve the quality of teacher performance.

\section{RESEARCH METHOD}

This study is a school action research conducted in two cycles in which each cycle consisted of two meetings, taking place from January to April 2020. The writer acted as the researcher, the collaborator for school principals, and the observer for teachers who carried out open class for zone-based lesson study. Three public schools were involved in cycle 1 and two public schools in cycle 2. The research subjects were the best teachers in their subjects: 1 Biology teacher and 1 History teacher from three schools in cycle 1; and 1 Math teacher and 1 Sociology teacher from two schools in cycle 2. The number of schools as the research subjects changed due to the new decree issued precisely at the end of cycle 1; thus, the supervision in cycle 2 complied with the new decree. The best teachers were determined by the results of UKG (Teacher Competency Test) and PKG (Teacher Performance Assessment) as well as the recommendations from teacher coordinators and school principals. On the other hand, the four subjects of natural and social sciences were selected based on teachers' readiness to become model teachers in other schools. The reason for choosing the subjects from two concentrations was because the schools as the research subjects divide the focus of studies into natural sciences and social sciences. Natural sciences were represented by Biology and Math teachers, while social sciences were represented by History and Sociology teachers. These teachers were prepared to become the zone organizer teachers in each school.

The research procedures involved observation and reflection on initial supervision in 2019, continued with giving treatments in two cycles including planning, implementation, observation, reflection, and follow-up. The planning stage involved designing programs for two cycles in accordance with the 2019 supervision program and developing instruments for two cycles (improving cycle 1) by creating review sheets for RPPs and teaching materials as well as observation sheets for open class implementation and student activities during the FTL implementation. The preparation in the planning stage was executed at the implementation stage that involved the Plan, Do, and See activities. The observation, conducted with the principals, TPMPS (School Quality Assurance Team) as well as teachers of cognate and non-cognate subjects, provided information about the strengths and weaknesses of the treatments. The results of reflection were used as the basis for the improvement of the next cycle and/or the supervision program the following year. The improvements for cycle 2 involved completing inadequate instruments in cycle 1 and revising the implementation 
process as well as adding instruments that were not present in cycle 1, such as students' responses to FTL and online learning. The second meeting of cycle 2 was performed online due to Covid19 pandemic (according to SE from Mendikbud, East Java Governor, and East Java Regional Head Office). Types of data, data sources, data collection technique, and research instrument are presented in table 1, 2 and 3 .

Table 1. Types of Instruments and Data Sources

\begin{tabular}{|c|c|c|}
\hline No & Types of Data & Data Sources \\
\hline 1 & Primary Data & $\begin{array}{l}\text { a. Results of review of RPPs in accordance with SE from } \\
\text { Mendikbud No. } 14 \text { of } 2019 \text { concerning the Simplification of } \\
\text { RPPs } \\
\text { b. Results of review of FTL teaching materials in the form of } \\
\text { UKBM or LKPD } \\
\text { c. Results of monitoring the implementation of FTL lessons } \\
\text { d. Results of monitoring student activities during FTL } \\
\text { program } \\
\text { e. Students' responses to the lessons implemented by } \\
\text { teachers }\end{array}$ \\
\hline 2 & $\begin{array}{l}\text { Secondary } \\
\text { Data }\end{array}$ & $\begin{array}{l}\text { a. TPMPS/PKG coordinators } \\
\text { b. Model teachers }\end{array}$ \\
\hline
\end{tabular}

Table 2. Types of Data, Data Description, and Data Collection Techniques

\begin{tabular}{|c|c|c|c|}
\hline No. & $\begin{array}{c}\text { Types of } \\
\text { Data }\end{array}$ & Data Description & $\begin{array}{c}\text { Data Collection } \\
\text { Techniques }\end{array}$ \\
\hline 1 & $\begin{array}{l}\text { Primary } \\
\text { Data }\end{array}$ & $\begin{array}{l}\text { Teacher performance, including: } \\
\text { a. Review of RPPs in accordance with SE } \\
\text { from Mendikbud No. } 14 \text { of } 2019 \\
\text { b. Review of teaching materials such as } \\
\text { UKBM or LPKD } \\
\text { c. Monitoring the implementation of } \\
\text { FTL lessons } \\
\text { d. Monitoring student activities during } \\
\text { FTL program } \\
\text { e. Students' responses to lessons } \\
\text { implemented by teachers }\end{array}$ & $\begin{array}{l}\text { a. Observation } \\
\text { b. Questionnaire }\end{array}$ \\
\hline 2 & $\begin{array}{l}\text { Secondary } \\
\text { Data }\end{array}$ & $\begin{array}{l}\text { a. UKG scores in } 2015 \\
\text { b. PKG results in } 2019 \\
\text { c. RPP } \\
\text { d. Teaching materials }\end{array}$ & $\begin{array}{l}\text { a. Document } \\
\text { analysis }\end{array}$ \\
\hline
\end{tabular}


Table 3. Research Instruments

\begin{tabular}{|c|c|c|}
\hline No. & Data Description & Research Instruments \\
\hline & $\begin{array}{l}\text { a. RPPs } \\
\text { b. Teaching materials } \\
\text { c. Review of RPPs in } \\
\text { accordance with SE from } \\
\text { Mendikbud No. } 14 \text { of } 2019 \\
\text { d. Review of teaching } \\
\text { materials } \\
\text { e. Observation on the } \\
\text { implementation of FTL } \\
\text { lessons } \\
\text { f. Students' responses to } \\
\text { FTL lessons }\end{array}$ & $\begin{array}{l}\text { 1) Observation } \\
\text { 2) Observation sheet for the } \\
\text { implementation of lessons in FTL } \\
\text { program } \\
\text { 3) Interview } \\
\text { 4) Interview sheet } \\
\text { 5) Questionnaire } \\
\text { 6) Questionnaire sheet for students' } \\
\text { responses to FTL lessons } \\
\text { 7) Document analysis } \\
\text { 8) Guidelines for RPP components in } \\
\text { accordance with the SE from } \\
\text { Mendikbud No. } 14 \text { of } 2019 \\
\text { concerning the Simplification of } \\
\text { RPPs } \\
\text { 9) Guidelines for the components of } \\
\text { FTL teaching materials } \\
\text { 10) Review sheet for RPPs in } \\
\text { accordance with SE from } \\
\text { Mendikbud No. } 14 \text { of } 2019 \\
\text { 11) Review sheet for FTL teaching } \\
\text { materials Review sheet for } 2019 \\
\text { PKG results } \\
\text { 12) Review sheet for } 2015 \text { UKG results }\end{array}$ \\
\hline
\end{tabular}

The research data were analyzed using a descriptive qualitative approach based on the observation results through the following steps: (1) reduction, i.e. checking and re-recording collected data; (2) interpretation, i.e. interpreting data in the form of statements; (3) inferences, i.e. inferring that the treatments given can improve teacher's and principal's competencies; (4) follow-up; i.e. designing steps for improvement in the next cycle and formulating follow-up for supervision program and/or guidance and training program for professional teachers and/or principals after PTS ends; and (5) conclusion, i.e. drawing conclusions from the analysis of observation findings according to the research objectives presented in statements of the results of interpretation (Christian, 2019). The indicators of the attainment of treatments in this study include: (1) the scores of RPPs, teaching materials, lesson implementation, and student activities of each model teacher have reached KKM (Minimal Completeness Criteria) (80); (2) the average scores of RPPs, teaching materials, lesson implementation, and student activities, which are calculated based on the scores of RPP, teaching materials, lesson implementation, and student activities of every meeting from the model teachers have reached KKM; (3) the score of teacher performance derived from the average scores of RPPs, teaching 
materials, lesson implementations, and student activities of the model teachers has reached KKM; (4) the score of teacher's performance quality calculated from the average score of teacher performance has reached KKM; and (5) the score of teacher performance improves from cycle 1 to cycle 2.

\section{RESULT AND DISCUSSION}

After PTS was conducted in two cycles in which each cycle consisted of two meetings, data of the quality of teacher performance were obtained. The data can be seen in Table 4 until Table 9 below.

Table 4. The Scores of Four Indicators of Teacher Performance for Two Meetings in Cycle 1

\begin{tabular}{lcccrrrrrr}
\hline & \multicolumn{2}{c}{ RPPs } & \multicolumn{2}{c}{$\begin{array}{c}\text { Teaching } \\
\text { Materials }\end{array}$} & \multicolumn{2}{c}{$\begin{array}{c}\text { Results of } \\
\text { Observation }\end{array}$} & \multicolumn{2}{c}{$\begin{array}{c}\text { Student } \\
\text { Activities }\end{array}$} \\
\cline { 2 - 10 } Subjects & Meet 1 & \multicolumn{2}{c}{$\begin{array}{c}\text { Meet } \\
\text { 2 }\end{array}$} & $\begin{array}{c}\text { Meet } \\
\mathbf{1}\end{array}$ & Meet 2 & Meet 1 & Meet 2 & Meet 1 & Meet 2 \\
\hline GR-A6 & 83.3 & 100 & 86 & 93.3 & 82.03 & 87.62 & 95.57 & 96.29 \\
\hline GR-A6 & 77.8 & 100 & 90 & 95 & 84.61 & 84.63 & 75.83 & 96.65 \\
\hline GR-A10 & 83.3 & 100 & 86 & 93.3 & 91.35 & 94.55 & 95 & 97.78 \\
\hline GR-A10 & 77.8 & 100 & 90 & 95 & 86.55 & 92 & 93.33 & 95.55 \\
\hline GR-NALA & 83.3 & 100 & 86 & 93.3 & 83.19 & 84.15 & 77.49 & 90 \\
\hline GR-NALA & 77.8 & 100 & 90 & 95 & 78.46 & 83.08 & 69.34 & 73.34 \\
\hline
\end{tabular}

Table 4 shows that all PTS subjects' scores of RPPs, teaching materials, lesson implementations, and student activities increased from meeting 1 to meeting 2, and each score reached KKM, except teachers with the codes of (GR-A6, GR-A10, dan GR-NALA) who obtained the RPP score of 77.8 in meeting 1 ; the teacher with the GR-NALA code obtained the score of 78.46 for the lesson implementation in meeting 1 ; the teacher with the code of GR-A6 and two teachers with the code of GR-NALA obtained the scores of 75.83, 77.49, and 69.34 for student activities; and the teacher with the code of GR-NALA obtained the score of 73.34 for student activities in meeting 2. The scores of four indicators of teacher performance in cycle 2 are illustrated in Table 5 below. 
Table 5. The Scores of Four Indicators of Teacher Performance for Two Meetings in Cycle 2

\begin{tabular}{|c|c|c|c|c|c|c|c|c|}
\hline \multirow[b]{2}{*}{ Subjects } & \multicolumn{2}{|c|}{ RPPs } & \multicolumn{2}{|c|}{$\begin{array}{l}\text { Teaching } \\
\text { Materials }\end{array}$} & \multicolumn{2}{|c|}{$\begin{array}{c}\text { Results of } \\
\text { Observation }\end{array}$} & \multicolumn{2}{|c|}{ Student Activities } \\
\hline & Meet 1 & Meet 2 & Meet 1 & Meet 2 & Meet 1 & Meet 2 & Meet 1 & Meet 2 \\
\hline GR-A10 & 100 & 100 & 86.36 & 100 & 87.98 & 87.98 & 90 & 90 \\
\hline GR-A10 & 100 & 100 & 100 & 100 & 86.53 & 86.53 & 83.34 & 83.34 \\
\hline $\begin{array}{l}\text { GR- } \\
\text { NALA }\end{array}$ & 100 & 100 & 86.36 & 100 & 98.08 & 98.08 & 94.81 & 94.81 \\
\hline $\begin{array}{l}\text { GR- } \\
\text { NALA }\end{array}$ & 100 & 100 & 100 & 100 & 93.75 & 93.75 & 90 & 90 \\
\hline
\end{tabular}

Table 5 illustrates that all subjects' scores of RPPs, teaching materials, lesson implementations, and student activities increased from meeting 1 to meeting 2, and each score reached KKM, except that the scores of lesson implementations and student activities in meeting 2 were obtained online due to the Covid-19 pandemic. The scores of meeting 2 were adopted from the scores of meeting 1 as a result of the impossibility of face-to-face observation. The following table describes the average scores of the four indicators of teacher performance in cycle 1.

Table 6. The Average Scores of the Four Indicators of Teacher Performance in Cycle 1

\begin{tabular}{lrr}
\hline \multicolumn{1}{c}{ Average Scores } & Meet 1 & Meet 2 \\
\hline RPP & 80.55 & 100 \\
\hline Teaching Materials & 88 & 94.15 \\
\hline Lesson Implementation & 84.37 & 87.67 \\
\hline Students' Activities & 84.43 & 91.61 \\
\hline
\end{tabular}

Table 6 shows that the scores of teacher performance increased from meeting 1 to meeting 2, and each score reached KKM. The average scores of the four indicators of teacher performance in cycle 2 can be seen in the table below.

Table 7. The Average Scores of the Four Indicators of Teacher Performance in Cycles 1 and 2

\begin{tabular}{lrr}
\hline \multicolumn{1}{c}{ Average Scores } & Meet 1 & \multicolumn{1}{c}{ Meet 2 } \\
\hline RPP & 100 & 100 \\
\hline Teaching Materials & 93.18 & 100 \\
\hline Lesson Implementation & 91.59 & 91.59 \\
\hline Students' Activities & 89.54 & 89.54 \\
\hline
\end{tabular}

The average scores of the four indicators of teacher performance in two cycles can be seen in Table 8. 
Table 8. The Average Scores of the Four Indicators of Teacher Performance in Two Cycles

\begin{tabular}{llcc}
\hline No & \multicolumn{1}{c}{$\begin{array}{c}\text { Indicators of Teacher } \\
\text { Performance }\end{array}$} & Cycle 1 & Cycle 2 \\
\hline 1 & RPPs & 90.28 & 100 \\
\hline 2 & Teaching Materials & 91.08 & 96.59 \\
\hline 3 & Learning Observation & 86.02 & 91.59 \\
\hline 4 & Student Activities & 88.02 & 89.54 \\
\hline
\end{tabular}

Table 8 shows that the four indicators of teacher performance saw an increase from cycle 1 to cycle 2 . The quality of teacher performance calculated from the average scores of the four indicators of teacher performance in both cycles are presented in Table 9 below.

Table 9. The Increase of Teacher's Performance Quality in Two Cycles

\begin{tabular}{cc}
\hline \multicolumn{2}{c}{ Quality of Teacher Performance } \\
\hline Cycle 1 & Cycle 2 \\
\hline 88.85 & 94.43 \\
\hline
\end{tabular}

Four answers to research problems are presented as the following. First, the strategy of zone-based lesson study by exchanging teachers can improve teacher's competency in designing FTL learning tools. The learning tools include RPPs and teaching materials such as UKBM and LKPD. This signifies that teachers are prepared for lesson implementation. According to Kristiani (2019), UKBM is created sequentially in an easy-to-difficult order as a learning tool. Furthermore, UKBM formulates activities in order to develop student competencies, including attitudes, knowledge, and skills. UKBM can be used as teaching materials to facilitate independent learning for students. Specific skills are required to plan UKBM because UKBM as teaching materials should be able to provide students with chances to think independently. Thus, the writer established the ability to plan UKBM as an indicator of teacher's performance quality. This also applies to LKPD; the quality of teacher performance can be indicated from LKPD. If LKPD can encourage students to perform intense activities, it is comprised of highperformance indicators. Thus, the ability to plan LKPD was also established by the writer to become the indicator of teacher's performance quality.

The success of the zone-based lesson study strategy by exchanging teachers in improving teacher's ability to develop learning tools, including RPPs and teaching materials, results from the implementation of the plan stage of the lesson study conducted collaboratively. The results are more effective because teachers with different work culture fostered in their original schools are now united in the same activity at the plan stage. This situation motivates teachers to become more critical, creative, communicative, and logical in preparing RPPs collaboratively. Then, the RPPs will be implemented at the Do and See stage in different schools. Teachers 
are allowed to present RPPs as creatively as possible, but it should be approved by three teachers from three target schools in cycle 1 and from two teachers from two target schools in cycle 2. The RPPs are composed in order to achieve basic competencies according to the 2013 curriculum (Permendikbud No. 37 of 2018). Widodo, et al. (2007) argued that professional development conducted collaboratively and sustainably in order to enhance the quality of learning processes and outcomes can use lesson study. This is in line with the finding of Soedarmanto (2009) that the task completion to achieve the common goals can be done through collaboration. Furthermore, according to Kristiani (2019), collaboration between school supervisors and principals can improve the quality of school performance in facilitating PKB (Sustainable Professional Development). These findings highlight the importance of collaboration, which was performed in this study.

Second, the zone-based lesson study strategy by exchanging teachers can improve teacher's abilities to implement lessons in FTL program. The follow-up of the plan stage is the Do and See stage, which was executed through open class by the model teachers. In this study, the model teachers exchanged target schools. In cycle 1, GR-A6 taught at A-10; GR-A10 taught at A-NALA; and GR-ANALA taught at A6. In cycle 2, since $A 6$ belonged to the target area of another supervisor, the research subject was released. As a result, GR-A10 taught at ANALA, and GR-ANALA taught at A10. The teacher exchange strategy provides teachers with challenging experiences because each teacher taught students of another school. Generally, teachers are more likely to attempt harder to succeed in front of unfamiliar students and to perform better than their colleagues. During open class, teachers had more optimal preparation of RPPs, teaching materials, learning media, learning sources, teaching techniques, and etc. All these learning tools were perfectly prepared. This process drives the improvement of teacher performance quality. This ability is part of pedagogical competence (PP No. 74 of 2008 concerning Teachers). Thus, teacher's pedagogical competence can be improved.

Third, the zone-based lesson study by exchanging teachers can improve student activities during FTL lessons. Effective, efficient, and student-oriented RPPs can improve student activities during the learning process (RPP Pocket Book of 2020). Student participation increased as a result of RPPs oriented to students and enhanced by proper teaching materials. Among four indicators of teacher's performance quality, the indicator of student activities during FTL program had the lowest score. There were four teachers whose scores were still below KKM in two cycles. This seems to be caused by the students' unfamiliarity with the new teachers or with FTL program, so they still felt reluctant to express themselves. However, this situation changed in the second meeting where students had already learned with the new teachers in the first meeting. The model teachers continuously motivated students to develop reasoning throughout the learning process. They were encouraged to be free from fears, to think, to act, to argue, to ask, and to be creative. This freedom needs to be trained to students continuously in order to develop their reasoning skill optimally during the learning process, which in turn enables them to produce creative and innovative ideas. Freedom, in this regard, requires responsibility to create harmony in society through reasoning skill. 
According to Kristiani, et al. (2015), such behavior is fostered by scientific attitude obtained through student-centered learning. Furthermore, Allen, et al. (2001) stated that there are three essential aspects of learning outcomes, namely cognitive, affective, and behavioral aspects. However, Kristiani (2014) pointed out that learning outcomes are influenced by students' metacognitive aspect gained through learning process. These findings support the current study's results that can encourage teachers to refine student activities to improve learning outcomes.

Fourth, the zone-based lesson study strategy by exchanging teachers can facilitate teachers to become zone organizers in each school. The plan, Do and See stage, followed up with reflection, enabled the writer as a school supervisor to continuously develop, monitor, assess, guide and train teachers during the treatments. This is an effective, efficient, and teacher-oriented technique. The model teachers recruited in this study were the best teachers in Biology, History, Mathematics, and Sociology in the target schools. They were given the reinforcement of concept at the plan stage and real experiences of FTL implementation at the Do and See stage. After the open class ended, the model teachers were given reinforcement and inputs for further improvement. This activity is an excellent means of eliminating misconceptions about learning so that teachers will be highly equipped to become zone organizer teachers in each of their schools.

Ratlin (2017) suggested that teacher's performance quality is influenced by the purpose of the academic supervision of school supervisors. Open class in this study aimed to optimize academic supervision, which can maintain and improve the quality of teacher performance. Through the zone-based lesson study by exchanging teachers, school supervisors have chances to serve zone organizers as individual teachers or teachers who join in subject teacher working group (MGMP). This strategy can also improve the previous strategy that was classically implemented. Classical development, supervision, assessment, guidance and training produced unsatisfactory results (Result of Evaluation of Supervision Program Implementation Report in 2019). Through individual development and guidance, teachers can grow more professionally and be more prepared to become zone organizer teachers in their schools. The strategy of zone-based lesson study by exchanging teachers can develop teacher professionalism as zone organizers. This is in parallel with the finding by Subadi, et al. (2013) that lesson study is one of the models for teacher professional development.

This study is inextricably linked with the supervisory tasks, which include the development of teachers and principals, the supervision of implementation of 8 National Education Standards (SNP), the assessment of performance of teachers and principals, and the professional guidance and training (Bimlat) of teachers and principals. The zone-based lesson study by exchanging teachers is part of the execution of supervisory tasks. This strategy can also improve the competency in research and development, which is one of the competencies of school supervisors and aims to execute the collective labor agreement (PKB) (Permendikbud No. 22 of 2016 and Permendikbud No. 15 of 2018). It can also improve the image of school supervisors as Iskandar \& Wibowo (2016) said that school supervisors have not 
shown their optimal performance. The supervision focused in this research is expanded into a wide range of activities, namely development, monitoring, assessment, guidance, and professional training of teachers and principals. It is expected that school supervisors can form a good partnership with schools. If school supervisors are actively involved, teachers will be more motivated to implement lessons more effectively (Slameto, 2016; Kristiani, 2019). This effort is aligned with the findings of the studies conducted by Nurhayati (2013) and Ratlin (2017), revealing that the better the school supervisor's performance, the better the teacher competency. In addition, there are positive impacts of the quality of academic supervision on teacher performance. Thus, the current study not only improves the image of school supervisors, but also supports the results of previous studies.

\section{CONCLUSION}

Four conclusions can be drawn in this research. First, the strategy of the zone-based lesson study by exchanging teachers can improve teacher competency in designing FTL learning tools. The improvement can be achieved if there is collaboration between teachers of different schools at the plan stage. The collaboration will enrich teacher's insights and creativity in designing RPP. Second, the strategy can improve teacher competency in implementing FTL lessons if lesson plans are properly prepared and enhanced by a situation that forces teachers to teach before unfamiliar students and other teachers. Third, the strategy can improve students' participation during FTL lessons if the lessons are planned specifically and accordingly for FTL program. The key is that if lesson plans are properly prepared, lessons can be properly implemented. Fourth, the strategy can facilitate teachers to become zone organizers in their schools. At the plan stage, teachers learn not only to collaborate, but also to comprehend the FTL concept and the RPP simplification in accordance with the correct guidelines. Teachers not only acquire comprehensive knowledge about FTL, but also have the opportunity to implement it at the Do and See stage. The reflection stage is also performed at the end of the meeting in every cycle. At the reflection stage, school supervisors, principals, and observers provide feedback, reinforcement, and suggestions for the next activities. The reflection can also extend teacher's knowledge and skills in teaching in order to become zone organizers. Through zone organizer teachers, peer tutoring activities can be conducted in each school. In addition to the four conclusions, the strategy can also facilitate the preparation of professional development in collaboration with supervisors, principals, and teachers.

Of the four concluded impacts of the strategy mentioned above, the most significant increase can be seen in the competency of designing RPP and teaching materials. This is due to the policy of the RPP simplification that can ease teacher's job of designing RPP. A significant increase is seen in the competency in designing teaching materials because the collaboration between schools can enrich teacher's creativity. However, the competency in implementing FTL lessons to improve students' participation increases slightly. This indicates that proper lesson plans cannot guarantee effective implementation. Thus, teachers are required to practice continuously. 


\section{REFERENCES}

Abidah, A., Hidaayatullaah, H. N., Simamora, R. M., Fehabutar, D., \& Mutakinati, L. (2020). The Impact of Covid-19 to Indonesian Education and Its Relation to the Philosophy of "Merdeka Belajar". SiPoSE: Studies in Philosophy of Science and Education, 1(1), 38-49.

Allen, D.E., Duch, B.J. \& Groh S.E. (2001). Strategies for Using Groups. In Duch. B.J et. (ed). The Power of Problem Based Learning: A Practical "How To" for Teaching Undergraduate Courses in Any Discipline. Sterling: Stylus Publishing.

Buku Saku Tanya Jawab Rencana Pelaksanaan Pembelajaran (RPP) Tahun 2020. Komisi Keteketik KWI. (Online), (https://komkat-kwi.org/2020/03/11/bukusaku-tanya-jawab-rpp-di-sekolah-dasar/), diakses 30 Maret 2020.

Danim, S. (2010). Inovasi Pendidikan: Dalam Upaya Peningkatan Profesionalisme Tenaga Kependidikan. Bandung: Pustaka Setia.

Elihami, E. (2019). Implementasi Layanan Bimbingan Kelompok dalam Meningkatkan Higher of Think Mahasiswa Berbasis Kampus Merdeka. EduPsyCouns: Journal of Education, Psychology and Counseling, 1(1), 79-86.

Iskandar, D., Wibowo, U.B. (2016). Peran Pengawas Pendidikan Dalam Peningkatan Mutu Pendidikan SMA di Kabupaten Bima Provinsi Nusa Tenggara Barat. Jurnal Penelitian Ilmu Pendidikan, 9 (2): 179-195,

Kristiani, N. (2014). Hubungan Keterampilan Metakognitif dan Hasil Belajar Kognitif Siswa pada Pembelajaran Pembelajaran Saintifik Dalam Pembelajaran Biologi SMA Kurikulum 2013. Makalah disajikan dalam Seminar Nasional XI Biologi, Sains, Lingkungan, dan Pembelajarannya, Program Studi Biologi Fakultas Keguruan dan Ilmu Pendidikan UNS, Surakarta, 8 September.

Kristiani, N. (2019). Peningkatan kualitas Kinerja Sekolah Melalui Pemanfaatan Supervisi Pembelajaran Berbasis Kolaboratif Dengan Pendekatan Sedayng TIpat Puter. Indonesian Journal of Educational Studies. 22(1): 23-34.

Kristiani, N., Susilo, H., Rohman, F., \& Corebima, D. A. (2015). The contribution of students' metacognitive skills and scientific attitude towards their academic achievements in biology learning implementing Thinking Empowerment by Questioning (TEQ) learning integrated with inquiry learning (TEQI). International Journal of Educational Policy Research and Review, 2 (9): 113-120.

Mustaghfiroh, S. (2020). Konsep "Merdeka Belajar" Perspektif Aliran Progresivisme John Dewey. Jurnal Studi Guru Dan Pembelajaran, 3(1), 141-147.

Nehru, N. A. (2019). Asesmen Komptenesi Sebagai Bentuk Perubahan Ujian Nasional Pendidikan Indonesia: Analisis Dampak dan Problem Solving Menurut Kebijakan Merdeka Belajar. Journal of Chemical Information and Modeling, 53(9), 1689-1699.

Nurhayati, S. (2013). Hubungan Kinerja Supervisor Dengan Tingkat Kompetensi Guru Sekolah Dasar di Kota Malang. Jurnal Kebijakan dan Pengembangan Pendidikan, 1 (2): 194-202.

Peraturan Menteri Pendidikan dan Kebudayaan Republik Indonesia Nomor 22 Tahun 2016 tengang Standar Proses pada Pendidikan Dasar dan Menengah. BSNP. (Online), (https://bsnp-indonesia.org/wpcontent/uploads/2009/06/Permendikbud_Tahun2016_Nomoro22.pdf), diakses 
30 Maret 2020.

Peraturan Menteri Pendidikan dan Kebudayaan Republik Indonesia Nomor 15 Tahun 2018 tentang Pemenuhan Beban Kerja Guru, Kepala Sekolah, dan Pengawas. LATEST Pendidikan Kewarganegaraan. (Online), (https://ainamulyana.blogspot.com/2018/05/permendikbud-nomor-15-tahun2018.html), diakses 30 Maret 2020.

Peraturan Menteri Pendidikan dan Kebudayaan Republik Indonesia Nomor 37 Tahun 2018 tentang Kompetensi Inti dan Kompetensi Dasar. (Online), (https://jdih.kemdikbud.go.id/arsip/Permendikbud\%20Nomor\%2037\%20Tahun\%2 02018.pdf), diakses 30 Maret 2020.

Peraturan Menteri Pendidikan dan Kebudayaan Republik Indonesia Nomor 43 Tahun 2019 tentang Penyelenggaraan Ujian yang Diselenggarakan Satuan Pendidikan dan Ujian Nasional. Kompas. (Online), (https://edukasi.kompas.com/read/2020/01/21/12391571/ada-permendikbud-43tahun-2019-bsnp-tak-lagi-terbitkan-pos-usbn?page=all), diakses 30 Maret 2020.

Peraturan Pemerintah Republik Indonesia Nomor 74 Tahun 2008 tentang Guru. Simpuh Kemenag. (Online), (http://simpuh.kemenag. go.id/regulasi/pp_74_08.pdf), diakses tanggal 30 Maret 2020.

Ratlin. (2017). Pengaruh Kualitas Supervisi Akademik Pengawas Sekolah Terhadap Kinerja Guru Sains SMAN Negeri di Kota Baubau. PEP Education Assesment, 1 (1): $17-26$

Slameto. (2013). Implementasi Eksplorasi, Elaborasi, dan Konfirmasi dalam Pembelajaran Guna Meningkatkan Kompetensi Pedagogik Guru SD. Salatiga: Tisara Grafika.

Slameto. (2016). Supervisi Pendidikan Oleh Pengawas Sekolah. Jurnal Manajemen Pendidikan, 3 (2): 192 -206.

Soedarmanto. (2009). Kinerja dan Pengembangan Kompetensi SDM. Yogyakarta: Pustaka Pelajar

Subadi, T., Khotimah, R.P, \& Sutarn, S.. (2013). A Lesson Study as a Development Model of Professional Teachers. Macrothink Institute International Journal of Education, 5 (2): 102-114

Supardi. (2013). Kinerja Guru. Jakarta: Raja Grafindo Persada.

Surat Edaran Mendikbud No. 3 Tahun 2020 tentang Pencegahan Covid-19 pada Satuan Pendidikan. Kementerian Pendidikan dan Kebudayaan. (Online), (https://www.kemdikbud.go.id/main/blog/2020/03/surat-edaran-pencegahancovid19-pada-satuan-pendidikan) diakses 16 Maret 2020.

Surat Edaran Gubernur Jawa Timur No 420/1780/101.1/2020 tentang Peningkatan Kewaspadaan terhadap Covud-19 di Jawa Timur. Liputan 6. (Online), (https://beritajatim.com/politik-pemerintahan/peningkatan-kewaspadaancovid-19-ini-isi-se-gubernur-jatim-ke-bupati-walikota/), diakses 16 Maret 2020.

Surat Edaran Kepala Dinas Pendidikan Provinsi Jawa Timur No. 420/1880/101.1/2020 tentang Tindak Lanjut Antisipasi Penyebaran Covid-19 di Satuan Pendidikan. Dindik Jatim. (Online), (https://twitter.com/dindik_jatim), diakses 23 Maret 2020.

Surat Edaran Menteri Pendidikan dan Kebudayaan Republik Indonesia Nomor 14 
Tahun 2019 tentang Penyederhanaan Rencana Pelaksanaan Pembelajaran. Kementerian Pendidikan dan Kebudayaan Republik Indonesia. (Online), (https://www.kemdikbud.go.id/main/blog/2019/12/surat-edaran-nomor-14tahun-2019-tentang-penyederhaan-rencana-pelaksanaan-pembelajaran), diakses 30 Maret 2020

Tilaar, H.A.R., (2000). Pendidikan Kebudayaan Dan Masyarakat Madani Indonesia: Strategi Reformasi Pendidikan Nasiolanl. Bandung: Remaja Rosdakarya.

Widodo, Ari, Sumarno, U., Nurjhani., M., dan Riandi. (2007). Peranan 'Lesson Study' dalam Peningkatan Kemampuan Mengajar Mahasiswa Calon Guru, Jurnal Veridika, 19 (1): 15-29. 